\title{
Reduction of air pollutants - a tool for control of atmospheric corrosion
}

\author{
V. Kucera*
}

\begin{abstract}
In most urban areas in Europe and Northern America serious corrosion impacts on buildings and cultural monuments have been caused by emissions of pollutants. The rapidly increasing pollution levels in many of the developing countries also exert a serious threat to materials. Beside the very important role of $\mathrm{SO}_{2}$ also the direct or synergistic effect of $\mathrm{NO}_{\mathrm{x}}$ and $\mathrm{O}_{3}$, the particulates and rain acidity may contribute in an important way to materials degradation. Results from extensive international field exposure programmes i.e. within the UN/ECE have enabled development of dose-response relations which describe the effect of dry and wet deposition of pollutants on corrosion of different material groups. In most of the industrialised countries decreasing trends of sulphur and nitrogen pollutants and of acidity of precipitation have resulted in decreased corrosion rates. The concept of acceptable levels of pollutants is a useful tool in planning of abatement strategies and for defining of conditions for a suitable development in the field of corrosion of constructions in the atmosphere.
\end{abstract}

Keywords Atmospheric corrosion. Multipollutant effects. Dose-response functions. Abatement strategies. Acid deposition.

\section{La reducción de la contaminación como forma de control de la corrosión atmosférica}

Resumen La contaminación de la atmósfera ha sido la principal razón del grave deterioro de las edificaciones y de los monumentos en numerosas ciudades de Europa y Norteamérica. De otro lado, el acelerado incremento de los niveles de contaminación en los países menos desarrollados está poniendo en peligro la estabilidad de los materiales utilizados. Además del importante papel que en este sentido juega el $\mathrm{SO}_{2}$, la acción directa o el efecto sinérgico de los $\mathrm{NO}_{x}$ y el $\mathrm{O}_{3}$, al igual que el material particulado y las lluvias ácidas contribuyen a agravar el problema. Resultados de vastos programas internacionales de investigación como, por ejemplo, el UN/ECE, han permitido desarrollar relaciones dosisrespuesta que describen el efecto de la deposición de los contaminantes sobre la corrosión de diferentes grupos de materiales. También se ha encontrado que, en la mayoría de los países industrializados, la tendencia a la disminución de la contaminación atmosférica ha contribuido a la reducción de las velocidades de corrosión. De aquí, ha surgido el concepto de niveles de contaminación tolerables, el cual constituye una poderosa herramienta en la planificación de estrategias para la prevención del deterioro y para la definición de condiciones más apropiadas frente al problema de la corrosión de las construcciones expuestas a la atmósfera, como forma de contribuir al logro de un desarrollo más ajustado a las necesidades de la sociedad.

Palabras clave Corrosión atmosférica. Contaminación atmosférica. Funciones dosisrespuesta. Estrategias de control de la contaminación. Lluvias ácidas.

\section{INTRODUCTION}

Air pollutants emitted at combustion of fossil fuels have since long time ago been acknowledged as responsible for increased atmospheric corrosion of several metallic and non-metallic materials. The problem was earlier mostly confined to urban areas in industrial countries, where high concentrations of pollutants and material densities coincide. The rapidly increasing pollution levels due to energy production and car traffic in many areas of the developing countries exerts today also a serious threat to materials including precious objects of cultural heritage. The experience of the last decades development in Europe and in Northern America shows, that a reduction of emissions of

(*) Swedish Corrosion Institute. Kräftriket 23A, 10405 Stockholm (Sweden). 
pollutants is a very efficient tool for control of atmospheric corrosion, which in its turn imply great savings of corrosion costs.

\section{INFLUENCE OF POLLUTANTS ON ATMOSPHERIC CORROSION}

Atmospheric corrosion is a process that occurs at a rate that is governed by meteorological parameters such as temperature, relative humidity and precipitation, which determine the time of wetness, and by the level of pollutants ${ }^{[1]}$. Beside this also some other natural parameters like air borne salt, UV-radiation, effects of freezing and microbiological activity can also be of great importance. In the present connection, however, the key question is to which extent the anthropogenic air pollutants accelerates the "natural" or background corrosion rate. This will also illustrate the possibility to control atmospheric corrosion by reduction of air pollutants. In this context it is useful to subdivide the effects of pollutants in the terms of "dry" and "wet" deposition. Wet deposition includes transport of pollutants by means of precipitation and is often affecting materials in remote areas by means of the long-range transport in the atmosphere. Dry deposition includes transport by any other processes and is usually dominating close to the pollution sources in urban and industrial locations ${ }^{[2]}$.

\subsection{Dry deposition effects}

In the field of atmospheric corrosion $\mathrm{SO}_{2}$ is the single most investigated gaseous pollutant. The decisive effect of $\mathrm{SO}_{2}$ on corrosion of inorganic materials like metals and calcareous stones is well established, while organic materials, such as painted surfaces, polymers and textiles are more sensitive to $\mathrm{O}_{3}$. In the last decade, however, a synergistic corrosive effect of $\mathrm{SO}_{2}$ and $\mathrm{NO}_{2}$ and later also of $\mathrm{SO}_{2}$ and $\mathrm{O}_{3}$ has been discovered under laboratory conditions as shown in figure $1^{[3]}$. Apart of the mentioned compounds also secondary pollutants like particulate sulphates and nitrates and nitric acid formed by further oxidation of $\mathrm{NO}_{2}$ should be mentioned as additional important constituents. Under conditions which are today found in several industrial countries, when $\mathrm{SO}_{2}$ is not more the dominating pollutant, a new multipollutant situation has developed, which give rise to multipollutant effects on materials ${ }^{[2-4]}$.

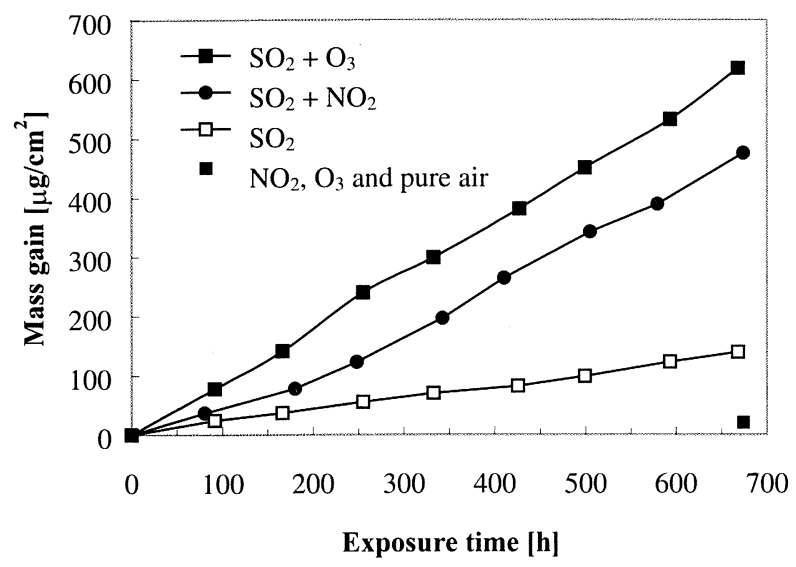

Figure 1. Mass gain of zinc samples exposed in air at $95 \%$ $\mathrm{RH}$; influence of $\mathrm{SO}_{2}(225 \mathrm{ppb}), \mathrm{NO}_{2}(400 \mathrm{ppb})$ and $\mathrm{O}_{3}$ $(400 \mathrm{ppb})$. Adapted from Svensson and Johansson ${ }^{[3]}$.

Figura 1. Ganancia de masa de muestras de cinc expuestas en aire a $95 \% \mathrm{HR}$; efecto del $\mathrm{SO}_{2}(225 \mathrm{ppb}), \mathrm{NO}_{2}(400$ ppb) y $\mathrm{O}_{3}(400 \mathrm{ppb})$. Adaptado de Svensson y Johansson ${ }^{[3]}$.

\subsection{Wet deposition effects}

Through wet deposition acidifying pollutants are brought to the surface with precipitation and for porous materials the acidic species can also be transported deeper into the material. For materials like zinc or copper this may lead to dissolution of protective corrosion products consisting of basic salts, as illustrated in figure 2 , which is based on the dose-response relation obtained within the UN/ECE ICP Materials Programme ${ }^{[4]}$. For other materials like carbon steel or aluminium the washing of the surface by rain causes a decrease of the corrosion rate in polluted areas compared to sheltered exposure.

\section{QUANTIFICATION OF EFFECTS - DOSE - RESPONSE RELATIONS}

During the last decades a number of field exposure programmes have been performed. Most of them have been confined to relatively small geographical areas and express corrosion on a local or regional basis. There are a few international exposure programmes which cover extensive geographical areas - the UN/ECE Programme ${ }^{[5]}$, the ISOCORRAG Programme ${ }^{[6]}$ and the MICAT Programme ${ }^{[7]}$. The weak point of most studies is usually the quality of environmental data, which is often inferior to the material degradation data. This presentation is confined to results obtained in the UN/ECE Programme, which was performed as 


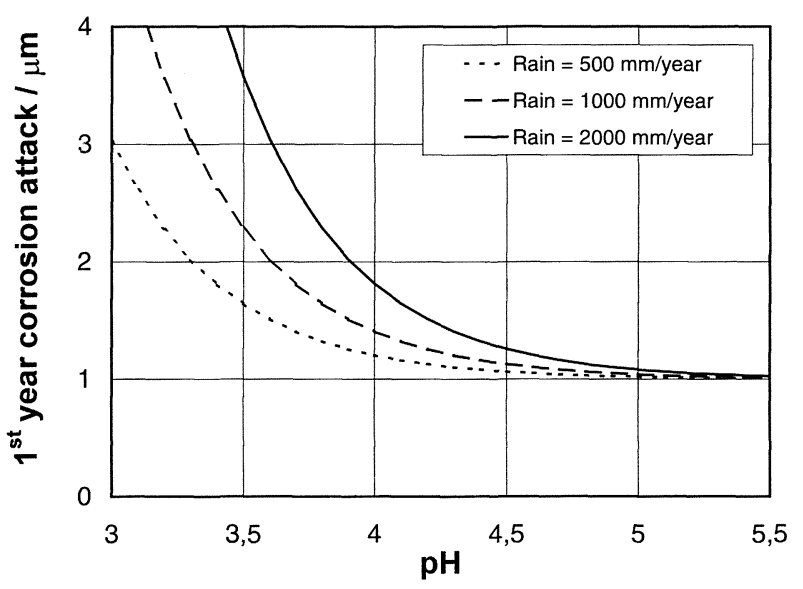

Figure 2. Corrosion attack on zinc vs $\mathrm{pH}$ of precipitation calculated from the dose-response relation given in table I with a dry deposition term corresponding to $1 \mu \mathrm{m}$. Curves are shown for the precipitation (Rain) values of 500, 1000, and $2000 \mathrm{~mm} /$ year.

Figura 2. Corrosión del cinc en función del pH de la precipitación, calculada con base en la relación dosisrespuesta dada en la tabla I, utilizando $1 \mu \mathrm{m}$ para el término de deposición seca. Se incluyen curvas para precipitaciones (lluvias) de 500, 1000 y 2000 mm/año.

a field exposure at 39 sites in a broad geographical region in Europe and in Northern America. The aim of the programme was to perform a quantitative evaluation of the effects of sulphur pollutants in combination with $\mathrm{NO}_{\mathrm{x}}$ and other pollutants as well as climatic parameters on the atmospheric corrosion of important materials.

The dose-response relations obtained should be suitable for mapping of areas with increased corrosion rates and for calculations of costs, which poses restrictions on the parameters that can be used. An important criterion is that the parameters should be easily available, which excludes the use of e.g. rain conductivity, intensity and frequency. This was also one reason why the time of wetness was replaced by temperature and relative humidity. As given above it is of importance for policy implications to be able to estimate the relative contribution of dry and wet deposition to the degradation of materials. Therefore only one type of dose-response relation was considered in which the corrosion attack, $K$, is described in terms of dry, $f_{\text {dry }}$, and wet, $f_{\text {wet }}$, deposition separated as additive terms

$$
K=f_{\text {dry }} \cdot t^{k}+f_{\text {wet }} \cdot t^{m}
$$

where $\mathrm{t}$ is the time and $\mathrm{k}$ and $\mathrm{m}$ are constants. The term for dry deposition for most materials includes
$\mathrm{SO}_{2}$ as a power function and the time of wetness has been replaced by temperature and relative humidity. This is a very important finding as it illustrates the importance of temperature for atmospheric corrosion with a maximum corrosion rate observed for many materials in the interval 9 . $11^{\circ} \mathrm{C}$, which is schematically shown in figure $3^{[4]}$. A choice of obtained dose-response relations is given in table I. In general care should be taken when extrapolating the equations outside the range of environmental parameters used for their calculations.

\section{ACCEPTABLE LEVELS OF POLLUTION AND CORROSION DAMAGE}

Atmospheric corrosion of materials is a cumulative, irreversible process that proceeds even in the absence of pollutants. The critical load/level approach used for ecosystems has to be modified in relation to degradation of materials as even the lowest concentration of pollutants causes an increase in the deterioration rate. This leads to the concept of acceptable corrosion rates and pollution levels. The acceptable corrosion rate should be based on technical and economic considerations taking into account the specific application of the material. For model calculations, however, and for comparison of different materials with respect to

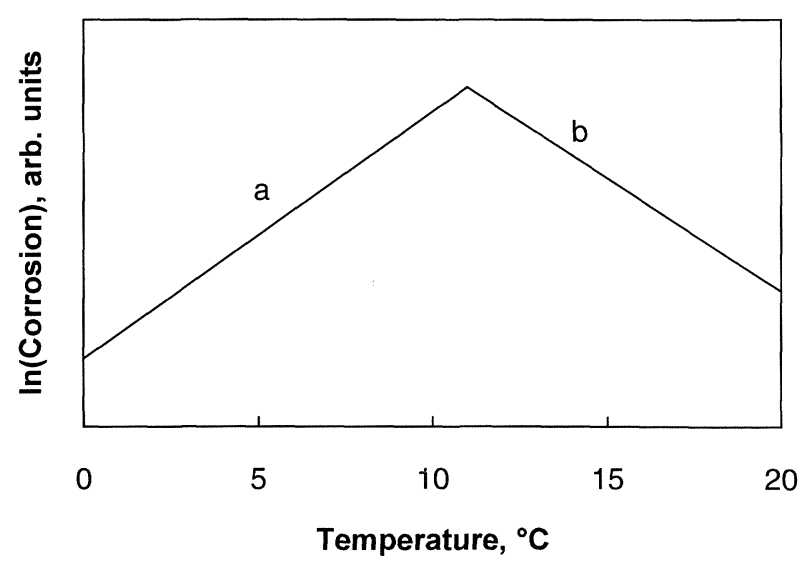

Figure 3. Schematic representation of the observed temperature dependence for many materials: a) increase of corrosion with temperature in the low temperature range and b) decrease of corrosion with temperature in the high temperature range ${ }^{[4]}$.

Figura 3. Representación esquemática del efecto del incremento de la temperatura sobre la velocidad de corrosión de diversos materiales: a) incremento de la corrosión en el rango inferior y b) disminución de la corrosión en el rango superior $^{[4]}$. 
Table I. List of dose-response functions, including temperature function, for unsheltered materials. The corrosion attack is expressed as mass loss ( $\mathrm{ML}$ in $\mathrm{g} / \mathrm{m}^{2}$ ) for metals, surface recession ( $R$ in $\mu \mathrm{m}$ ) for stone materials, ASTM D $1150-55$ rankings 11 to 10 where 10 means a fresh sample and 1 a completely degraded) for paint coatings or depth of leached layer (LL in $\mathrm{nm}$ ) for glass. Abbreviations of parameters: time ( $\mathrm{t}$ in year), temperature ( $\mathrm{T}$ in ${ }^{\circ} \mathrm{C}$ ), relative humidity $(\mathrm{Rh}$ in $\%), \mathrm{SO}_{2}, \mathrm{NO}_{2}, \mathrm{O}_{3}$ concentrations (in $\mu \mathrm{g} / \mathrm{m} 3$ ), rainfall (Rain in $\mathrm{mm}$ ), $\mathrm{H}^{+}$and $\mathrm{Cl}^{-}$concentrations (in $\mathrm{mg} / \mathrm{l}$ ). All parameters given as annual averages $^{[4]}$.

Tabla I. Listado de funciones dosis-respuesta, que incluye la función temperatura para materiales a la intemperie. El ataque corrosivo para los metales es expresado como pérdida de masa $\left(\mathrm{ML}\right.$ en $\left.\mathrm{g} / \mathrm{m}^{2}\right)$, como superficie alterada $(R$ en $\mu \mathrm{m})$ para los materiales pétreos, la clasificación de la ASTM D 1150-55 para las superficies pintadas (de 1 a 10, donde 10 significa completa limpieza y 1 completo deterioro), profundidad de la capa lixiviada (LL en $\mathrm{nm}$ ) para el vidrio. Las abreviaturas de los diferentes parámetros son: tiempo (t en años); temperatura $\left(T\right.$ en $\left.{ }^{\circ} \mathrm{C}\right)$; humedad relativa (Rh en \%); concentraciones de $\mathrm{SO}_{2}, \mathrm{NO}_{2}$ y $\mathrm{O}_{3}$ (en $\mu \mathrm{g} / \mathrm{m}^{3}$ ); lluvia (Rain en $\mathrm{mm}$ ); concentraciones de $\mathrm{H}^{+}$y Cl (en $\mathrm{mg} / \mathrm{l}$ ). Todos los parámetros son dados como promedios anuales ${ }^{[4]}$.

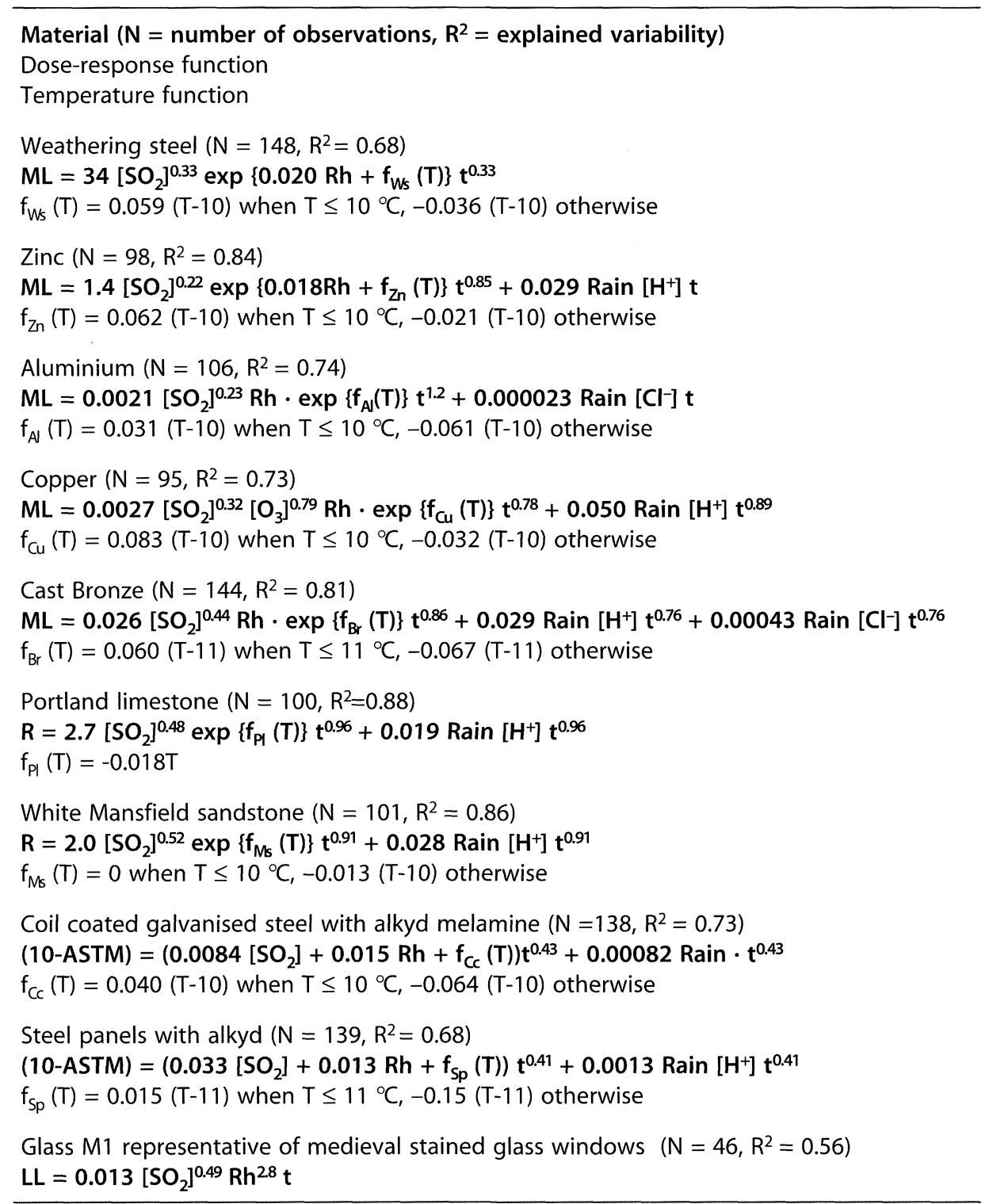

their pollution sensitivity, different levels of acceptance can be defined by relating the corrosion rate to corrosion rates in background areas. It has proven useful to define a factor, $n$, which is dimensionless and express the ratio between acceptable corrosion rate $\left(K_{a}\right)$ and the background corrosion rate $\left(K_{10} \%\right)$, which is calculated as the lower 10-percentile from the ICP Materials data set,

$$
n=K_{a} / K_{10} \%
$$


Using different $n$ values, typically $1.2,1.5$ or 2.0 , it is possible to calculate acceptable corrosion rates and, provided that dose-response relations are available, acceptable pollution levels for different materials. This concept is useful for mapping areas with elevated corrosion attack at different pollution scenarios and could be used as a tool for rational decisions on reductions of emissions of pollutants ${ }^{[8]}$.

\section{COSTS FOR AIR POLLUTION DAMAGE TO MATERIALS}

The costs of corrosion damage caused by acidifying air pollutants on materials are of great interest for cost-benefit analysis in connection with major investments or regulatory actions in order to reduce emissions. A model has been developed that comprises the determination of amounts, geographical distribution and corrosion status at inspections of randomly selected buildings in different pollution strata. A schematic description of the different steps included in the model is shown in figure $4^{[9]}$.

The damage functions can be obtained from dose-response functions or even more closer to the reality from observations of physical damage at the inspection of selected buildings and from well documented guidelines for maintenance intervals of buildings. The estimated economic damage can then be calculated as

$$
K_{\mathrm{add}}=K S\left(1 / L_{p}-1 / L_{c}\right)
$$

where $K_{\text {add }}$ is the additional cost for maintenance/ replacement, $K$ is the cost for maintenance/ replacement, $S$ is the surface area of material, $L_{p}$ is the maintenance area in polluted areas, and $L_{c}$ is the maintenance area in clean areas. A recent study using the described model has shown that the total cost savings in Europe from reduced damage to buildings, after implementation of the second sulphur protocol issued by UN/ECE within the Convention on Long-Range Transboundary Air Pollution, are in total over 9,000 millions US $\$$ year. The damage included reduced lifetime of galvanised steel structures, more frequent maitenace painting of steel structures and wooden constructions and damage caused to rendering on facades and to roofs covered by bitumen felt ${ }^{[10]}$.

\section{CONTROL MEASURES AND TRENDS IN POLLUTION AND CORROSION ATTACK}

The first agreement to control transboundary air pollution was adopted in 1979 by signing the UN/ECE Convention on Long-Range Transboundary Air Pollution by 32 European states plus Canada and the United States. In two protocols added to the Convention in 1985 and in 1994 far going further reductions of sulphur emissions have been agreed and implemented. In addition protocols on reduction of nitrogen oxides (1988), volatile organic compounds (1991) which concern groundlevel ozone, and finally the last multipollutant protocol to abate acidification, eutrophication and ground-level ozone (1999) have contributed to an improvement of the pollution situation in the ECE region. A key question in this connection is if the abatement strategies which have resulted in a substantial decrease especially in sulphur emissions have affected the deterioration rates of materials.

One of the aims of the UN/ECE ICP Materials Programme is to perform trend exposures to elucidate the effects of pollutant reductions and to identify extraordinary environmental changes that result in unpredicted environmental damage. The trend exposure consisted of repeated 1-year

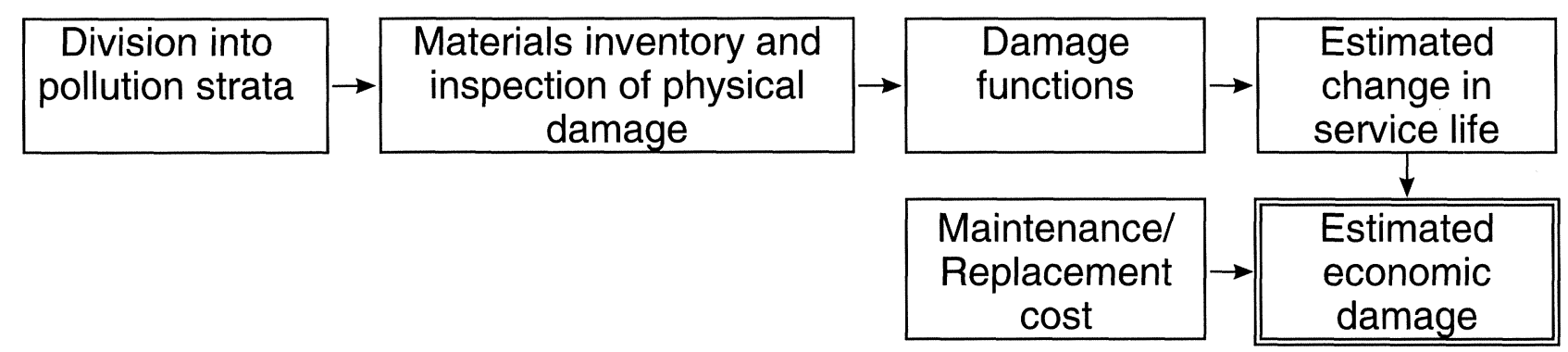

Figure 4. Schematic presentation of the main steps of the model for estimating economic damage.

Figura 4. Representación esquemática de los principales pasos del modelo para la estimación del daño económico. 
exposure of carbon steel and zinc on 39 test sites in the period 1987-1995. As shown in figure 5 of the environmental parameters measured in the network of urban and rural sites only $\mathrm{SO}_{2}, \mathrm{NO}_{2}$ and $\mathrm{H}^{+}$exhibit trends ${ }^{[4}$ and 11].

All of these are decreasing with $\mathrm{SO}_{2}$ having the strongest and $\mathrm{NO}_{2}$ the weakest trends. The decreasing trend in the levels of acidifying air pollutants has resulted in decreasing corrosion rates of carbon steel and zinc both in open and rain sheltered positions. A more detailed analysis shows that $\mathrm{SO}_{2}$ is the largest single factor to the decreasing corrosion trends. The decreasing $\mathrm{H}^{+}$ concentration in precipitation is also a contributing factor, its effect is however much smaller than that of dry deposition. A part of the drop cannot be directly related to a specific pollutant, but reflects the multipollutant character of the process of materials degradation. Likely contributors are particulates not measured in the programme, and synergistic effects of $\mathrm{SO}_{2}$ and $\mathrm{NO}_{2}$ and/or ozone.

The situation is, however, by far not so optimistic on a global scale. The extensive use of fossil fuels in Europe and in Northern America has dominated the global release of $\mathrm{SO}_{2}$ and $\mathrm{NO}_{x}$ to the atmosphere. With only about $14 \%$ of the world population these two regions currently emit about $70 \%$ of each species. The prognosis to the

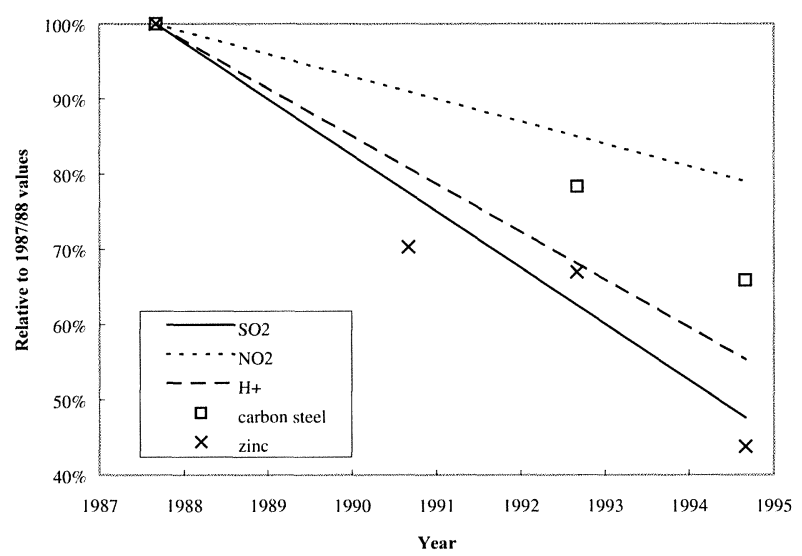

Figure 5. Trends of $\mathrm{SO}_{2}, \mathrm{NO}_{2}$, rain acidity $\left(\mathrm{H}^{+}\right)$, and corrosion of carbon steel and zinc. All values are expressed relative to the initial $(1987 / 88)$ value. For environmental data the average trend during the 8 -year period is indicated $^{[11]}$.

Figura 5. Tendencias en las concentraciones de $\mathrm{SO}_{2}$ y $\mathrm{NO}_{2}$, acidez de la lluvia $\left(\mathrm{H}^{+}\right)$y corrosión del acero al carbono y del cinc. Todos los valores están expresados respecto al valor inicial (1987/88). En el caso de los datos ambientales se presentan las tendencias promedios durante el período de los 8 años considerados ${ }^{[11]}$. years 2025 show a dramatic change. While the emissions in Europe and Northern America are projected to decrease the existing and growing role of emissions from South/Central America, Africa and especially Asia is a matter of serious concern. The amounts of data from systematic corrosion exposure programmes in tropical and subtropical countries are not sufficient for quantification of the effects of dry and wet deposition of acidifying air pollutants as especially the $\mathrm{pH}$ data are scarce. However, a recent overview has concluded that as many of the developing countries are located in warm regions with high relative humidity and high frequency of precipitation, there is an obvious risk that corrosion damage due to acid deposition will be serious and even higher than in the temperate zone with similar pollution ${ }^{[12]}$.

\section{CONCLUSIONS}

Dose-response functions developed on basis of the results from the UN ECE ICP Materials exposure programme for several materials used in technical constructions and objects of cultural heritage permits quantification of the effect of dry and wet deposition of pollutants.

The equations show that $\mathrm{SO}_{2}$ is for most materials the most important pollution parameter. In industrial countries, where the $\mathrm{SO}_{2}$ levels have decreased substantially, also nitrogen pollutants, ozone and particulates are today important constituents in the multipollutant situation.

The trend of reduction of pollutant levels due to international abatement strategies has resulted in a decreasing trend of corrosion rates in Europe and in Northern America.

Reduction of emissions of anthropogenic sulphur and nitrogen pollutants is an efficient tool for reducing the costs caused by atmospheric corrosion.

The concept of acceptable levels of pollutants is a useful tool in planning of abatement strategies and may also serve for defining conditions for a suitable development in the field of corrosion control of constructions in the atmosphere.

The cost for air pollution damage to materials as well as the damage to objects of cultural heritage in Europe and in Northern America is huge. The figures should serve as a warning in the process of industrialisation of developing countries. The importance of pollution control should be emphasised as the damage due to acid deposition 
could be even worse in the warm and humid climate, where many of these countries are situated.

\section{REFERENCES}

[1] V. Kucera and E. Mattsson, Corrosion Mechanisms, Marcel Dekker, New York 1987, pp. 211-284.

[2] V. Kucera and S. Fitz, Water, Air and Soil Pollut. 85 (1995) $153-165$.

[3] J.E. Svensson and L.G. Johansson, J. Electrochem. Soc. 140(1993), 2210-2216.

[4] J. Tidblad, V. Kucera and A. Mikhailov, UN/ECE Report No. 30, Swedish Corrosion Institute, Stockholm, Sweden, 1998.

[5] UN/ECE Report No. 1, Swedish Corrosion Institute, Stockholm, Sweden, 1987.

[6] D. KnotKova, P. BoscheK and K. Kreislova, Atmospheric Corrosion, W.W. Kirk and H.H. Lawson (Eds.), ASTM STP 1239, American Society for Testing and Materials, Philadelphia, U.S.A., 1994, pp. 38-55.

[7] M. Morcillo, Atmospheric Corrosion, W.W. Kirk and H.H. Lawson (Eds.), ASTM STP 1239, American Society for Testing and materials, Philadelphia, U.S.A., 1994, pp. 257-275

[8] V. Kucera and J. Tidblad, Proc. UN/ECE, Umweltbundesamt, Berlin, Germany, 1988, V. Kucera and S. Fitz (Eds.), 1998, pp. 173-178.

[9] V. Kucera, J. Henriksen, D. Knotkova and CH. Sjöström, Proc. $10^{\text {th }}$ European Corrosion Congress, Barcelona, Spain, 1993, Vol. 1, J.M. Costa and A.D. Mercer (Eds.), The Institute of Material, London, U.K., 1993, p. 242.

[10] D.A. Cowell and H.M. Apsimon, Estimating the Reduced Damage to Buildings in Europe Due to Implementation of the Second Sulphur Protocol, in: V. Kucera, David Pearce and Y-W. Brodin (Eds.), UN/ECE Workshop, V. Kucera, D. Pearce and Y-W. Brodin (Eds.), Royal Society of Arts, London, U.K., 1996, pp. 211-216.

[11] J. Tidblad, V. Kucera, A. Mikhailov, J. Henriksen, K. Kreislova, T. Yates, BV. Stöckle and M. Schreiner, Proc. $14^{\text {th }}$ Int. Corrosion Congress, Cape Town, S. Africa, 1999, Paper 337.1.

[12] J. Tidblad, A. Mikhailov and V. Kucera, Report 2000:8E, Swedish Corrosion Institute, Stockholm, Sweden, 2000. 